Review article

\title{
The genetics of idiopathic torsion dystonia
}

\author{
N A Fletcher
}

Idiopathic torsion dystonia (ITD) is a disorder of the central nervous system which produces dystonic movements and postures. The spectrum of severity is wide, including severe generalised dystonia (formerly termed dystonia musculorum deformans), segmental dystonia, and focal dystonias such as torticollis, blepharospasm, and writer's cramp (table). No other neurological deficits occur in ITD, although some patients display a postural tremor that is clinically indistinguishable from essential tremor. ${ }^{1}$ Although ITD is frequently inherited, ${ }^{2}$ the genetics of the condition have only recently become clear after decades of controversy.

This disorder is not rare; the most recent estimate of prevalence (from the United States) is approximately 1 in $3000^{3}$ and a strikingly high frequency among Ashkenazi Jews has long been apparent. ${ }^{5}$ ITD may develop at almost any age and this is the key factor determining its severity; generalised ITD almost always starts before the age of 20 years whereas focal

Classification of dystonia by anatomical extent.

Focal: one body part affected, examples include:

Blepharospasm (eyes)

Torticollis (neck)

Oromandibular dystonia

Spasmodic (adductor) laryngeal dystonia

Whispering (abductor) laryngeal dystonia

Writer's cramp (arm)

Segmental: two or more contiguous parts affected:

Cranial: 2 or more parts of cranial or neck musculature affected Brachial: 1 arm + axial (neck or trunk) or 2 arms \pm axial (neck or
trunk) affected

Axial: neck + trunk affected

Crural: 1 leg + trunk or both legs \pm trunk

Generalised: segmental crural plus any other part affected

Multifocal: 2 or more non-contiguous areas affected.

Hemidystonia: ipsilateral arm and leg affected.

Department of Neurology, The National Hospital for Nervous Diseases, Maida Vale, London W9 ITL. N A Fletcher
ITD usually begins in older adults. Some adult onset cases are very mild and often asymptomatic. ${ }^{6}$ The distribution of ages of onset is bimodal, suggesting that ITD may be heterogeneous. ${ }^{7}$ This bimodality arises because generalised ITD is of early onset and focal cases usually start after the age of $40^{8}$; segmental cases, of intermediate severity, tend to arise at all ages. Although generalised and focal cases may occur within single families with ITD ${ }^{6}$ it is widely suspected that, overall, the latter are the main source of heterogeneity in ITD. ${ }^{2}$

ITD must be distinguished from the symptomatic (or secondary) dystonias, a highly heterogeneous group of conditions with either known underlying causes or characteristic clinical features, and further investigations are required before the diagnosis is secure. ${ }^{8}$ In ITD, no abnormality is detectable by biochemical, immunological, haematological, or other laboratory tests. Electroencephalography, psychometry, computerised tomography, and magnetic resonance imaging of the brain are normal as is the cerebrospinal fluid. ${ }^{9}$ However, abnormalities can be detected by specialised electrophysiological techniques, thereby indicating a physiological basis for the dystonia. $^{10}$

The most important differential diagnoses of ITD are: athetoid cerebral palsy; exposure to neuroleptic drugs; structural lesions of the basal ganglia such as tumours or strokes; Wilson's disease, HallervordenSpatz disease, and other degenerative and metabolic disorders; and the delayed effects of encephalitis lethargica. ${ }^{9}$ To this list should be added dopa responsive dystonia (DRD), which is dominantly inherited and may resemble ITD closely, but responds dramatically to levodopa. ${ }^{11}$

The aetiology of ITD is unknown, but a biochemical disorder of the basal ganglia is suspected, ${ }^{12}$ principally because, so far, no structural lesion of the brain has been consistently identified. ${ }^{13}$

Early genetic studies in ITD

Familial cases of ITD have been frequently reported 
for almost 80 years. In his classic report, Schwalbe ${ }^{14}$ described a Jewish Lithuanian family containing three sibs with a severe movement disorder. Interestingly, their mother had developed involuntary movements of one arm and her father had developed a tremor after an injury. Subsequently, one of Schwalbe's patients had two similarly afflicted children. ${ }^{15}$ It seems beyond doubt that the illness in this family was ITD and that inheritance was autosomal dominant; they were studied over many years and neuropathological studies of two affected members were normal. ${ }^{15}$ Autosomal dominant ITD was later described in other kindreds, ${ }^{16}$ but there were also reports of apparently recessive inheritance. ${ }^{17} 18$ Moreover, many cases did not appear to have affected relatives, which led some to doubt that ITD was hereditary. ${ }^{19-21}$

\section{Autosomal dominant inheritance}

This confusing situation was clarified by Zeman et al, ${ }^{6}$ who described a large kindred with autosomal dominant ITD, but also showed that earlier reports of recessive inheritance were largely unreliable. Often, the diagnosis of ITD had been questionable, few family members had been examined, or the wide variety of ITD manifestations had not been recognised and mildly affected relatives had been discounted. Furthermore, increased parental consanguinity had not been reported. Overall, it seemed that when ITD was familial it was almost always inherited as a dominant trait, but that there was another large group of patients without any affected relatives. ${ }^{6}$ With regard to the latter, Zeman et $a l^{22}$ stressed the existence of very mild, sometimes asymptomatic, cases ('formes frustes') of ITD and suggested that mildly affected relatives of these patients could have been overlooked. In addition, it was suggested that some single cases might be the result of new dominant mutations. ${ }^{623}$ Several subsequent studies agreed with this analysis, describing dominantly inherited ITD with reduced penetrance and variable expression, including focal dystonia and postural tremor. ${ }^{23-26}$

\section{Autosomal recessive inheritance}

It was the long observed excess of Jewish ITD cases which led Eldridge ${ }^{27-29}$ to propose the existence of an autosomal recessive form of ITD, especially among Jews. Eldridge studied 96 North American families and reported that Jewish cases (37\% of the total) were usually isolated or had only affected sibs and were more severe than non-Jewish patients, as might be expected with a recessive variant. Segregation analysis among sibs (assuming truncate ascertainment) was consistent with recessive inheritance and a gene frequency of $1 / 130$ was calculated for the Ashkenazi Jewish population of the USA. It was notable that some Jewish cases had affected parents but this was attributed to pseudodominance. ${ }^{28}$

The existence of a recessive form of ITD, mainly among Jews, has been widely accepted for almost 20 years, despite numerous difficulties with this interpretation. ${ }^{30}$ In Eldridge's study no increase in parental consanguinity was observed and the number of Jewish cases with affected parents or offspring was much too large to be accounted for by pseudodominance. There was considerable ascertainment bias, truncate ascertainment was improbable, and diagnostic criteria for ITD were questionable. Examination of the published clinical data did not show striking differences between Jewish and nonJewish cases, and recent studies ${ }^{31} 32$ have confirmed that ITD is clinically similar in Jewish and nonJewish patients. More seriously, a recessive model was never able to account for the high empirical recurrence risk to children of Jewish cases, acknowledged to be almost $10 \%{ }^{29}$

In a later study of 32 British families (two of which were Jewish), the existence of both recessive and dominant cases could not be excluded but reduced fitness and an increased paternal age effect were found among isolated cases of childhood onset generalised ITD, suggesting that some of these might be the result of fresh dominant mutation. ${ }^{2}$ It was suspected that late onset cases with non-generalised ITD were usually non-genetic phenocopies but that a few were autosomal dominant cases. ${ }^{2}$

More recent reports of autosomal recessive ITD have been of doubtful significance. In a family containing three affected sibs, ${ }^{33}$ the diagnosis of ITD was questionable, as one sib had pyramidal signs. In four Gypsy families from Spain, ${ }^{34}$ the pedigrees were consistent with recessive ITD but in several patients the clinical features were unusual. In three of the families the parents were first cousins but the significance of this should be assessed in the light of an overall rate of consanguineous marriage in this population of over $50 \%$. Moreover, it was not clear whether parents or children of the patients had been examined.

\section{$\mathbf{X}$ linked inheritance}

A condition similar to ITD has been described on the island of Panay in the Philippines. ${ }^{35}$ Onset was from 12 to 51 years and all 28 cases were males with no documented male to male transmission. A recent study of this population has emphasised that the patients have parkinsonism as well as dystonia, which suggests that this disorder is not ITD. ${ }^{36}$ Although a slight excess of males with ITD (ratio 3:2) has been reported by some authors, ${ }^{6}$ there does not appear to be any difference in severity between male and female cases. ${ }^{37}$ Overall, it is unlikely that $\mathrm{X}$ linked inheritance is an important mode of inheritance of ITD. 


\section{Recent investigations}

Studies in Israel, ${ }^{38}$ the USA, ${ }^{39}$ and the $\mathrm{UK}^{37}$ have suggested that a recessive form of ITD may not exist at all, even among Ashkenazi Jews. In order to minimise heterogeneity, these studies were restricted to patients with generalised or segmental disease ${ }^{3738}$ or patients with onset before 28 years. ${ }^{39}$ This was because heterogeneity in ITD is thought to exist mainly among patients with later onset focal dystonia. ${ }^{2}$ As many relatives as possible were examined in order to detect mildly affected relatives.

In Israel, investigations of the families of 47 Jewish patients ${ }^{38} 40$ have clearly indicated autosomal dominant inheritance; the data were not compatible with a recessive model: Penetrance was reduced ( 51 to $68 \%$ ) and clinical expression was variable, including focal dystonia and tremor. Again, reduced fitness and increased paternal age were observed among single cases. More recently, autosomal dominant inheritance has also been shown in 39 North American Jewish families. Penetrance was estimated to be $30 \%$, assuming that all cases were genetic with no phenocopies. $^{39}$

An analysis of 100 British families containing 107 index cases (of which 11 were Jewish) with generalised, multifocal, and segmental ITD has shown that the inheritance of ITD in the UK is similar to that seen in Jewish populations in Israel and the USA ${ }^{37}$ The data suggested that about $85 \%$ of non-focal ITD is caused by a dominant gene with $42 \%$ penetrance; approximately $15 \%$ of cases were thought to be non-genetic phenocopies but could not be identified clinically. There was no evidence of genetic heterogeneity and, in particular, no clinical or genetic differences between Jewish and non-Jewish cases were detected. It is important to note that familial cases were clinically indistinguishable from single cases. Fitness was reduced to $66 \%$ and paternal age was significantly increased among single cases; it was estimated that $14 \%$ of inherited cases were new mutations. There was no evidence of $\mathrm{X}$ linked inheritance and the data were not compatible with polygenic inheritance. Negligible intrafamilial correlations for age of onset and dystonia severity scores ${ }^{41}$ suggested that environmental factors mainly determine the ITD phenotype. As in other studies, clinical manifestations of ITD among secondary cases ranged from generalised to focal dystonia and a few relatives had only a postural tremor. Tremor has long been recognised in dystonic patients ${ }^{142}$ and patients with essential tremor sometimes have signs of dystonia. ${ }^{4344}$ Moreover, relatives with tremor have been detected in almost all previous genetic studies of ITD. ${ }^{625} 2738$ A shared pathophysiology between dystonia and tremor has been suggested ${ }^{45}$ and patients with essential type tremor may be at increased risk of developing dystonia. ${ }^{46}$ Accordingly, it is likely that a postural tremor is the only manifestation of ITD in some affected relatives. Regarding the larger than expected number of cases among Ashkenazi Jews, the most likely explanation for this is genetic drift in small Jewish populations in Belorussia and the Baltic area in earlier centuries. ${ }^{35} 47$

\section{Genetic counselling}

Data are now available for genetic counselling if a family contains a case of generalised, multifocal, or segmental ITD. However, it is important to establish first whether a patient is a familial or an isolated case. It is therefore essential that relatives are carefully examined for signs of dystonia, which may be subtle. In the $\mathrm{UK},{ }^{37}$ the risk to first degree relatives of a familial case is estimated to be $21 \%$; if the index case is isolated, the risks are $14 \%$ to children and $8 \%$ to sibs. These figures may be reduced the longer the subject at risk has remained normal; approximately 50,75 , and $90 \%$ of secondary cases had developed dystonia at the ages of 15,30 , and 50 years, respectively. ${ }^{37}$ Furthermore, the risks refer to the likelihood of any of the varied manifestations of ITD. The risk of severe disability may best be gauged by looking at the secondary cases detected in the UK study; only about a half of these had severe dystonia.

Concerning the risks to relatives of patients with focal ITD, the figures discussed above may be applied only if there is another member of the family with generalised or segmental disease. If this is not the case, there are no reliable figures at present. The genetic studies already mentioned have shown that some cases of focal dystonia must result from the gene that causes generalised and segmental ITD, but the size of this proportion, in what is probably a heterogeneous group, ${ }^{48} 49$ is unclear.

\section{Future prospects}

An exciting development has been the recent discovery in a large North American kindred of linkage between autosomal dominant ITD and the gelsolin (GSN) gene locus on chromosome $9(9 q 32-34) .{ }^{50}$ The close proximity to the dopamine $\beta$ hydroxylase (DBH) gene at $9 \mathrm{q}^{34^{51}}$ is interesting, as abnormal DBH levels have been claimed in ITD. ${ }^{52}$ It will be interesting to see whether linkage between $G S N$ and ITD can be shown in other families or whether different ITD loci exist. If linkage between $G S N$ and ITD is confirmed in other families, the value of prenatal testing or presymptomatic testing of subjects at risk may be limited; only about $40 \%$ of those who carry the ITD gene will develop the disease and, of these, many will be only mildly affected.

1 Marsden CD, Harrison MJG. Idiopathic torsion dystonia (dystonia musculorum deformans). A review of 42 patients. Brain 1974;97:793-810.

2 Bundey S, Harrison MJG, Marsden CD. A genetic study of torsion dystonia. $\mathcal{F}$ Med Genet 1975;12:12-9. 
3 Nutt JG, Muenter MD, Aronson A, Kurland LT, Melton LJ III. Epidemiology of focal and generalised dystonia in Rochester, Minnesota. Movement Disorders 1988;3:188-94.

4 Zador J. Le spasme de torsion: parallele des tableaux cliniques entre la race juive et les autre races. Rev Neurol 1936;66:365-89.

5 Alter M, Kahana E, Feldman S. Differences in torsion dystonia among Israeli ethnic groups. In: Eldridge $R$, Fahn $S$, eds. Dystonia. Advances in neurology. Vol 14. New York: Raven Press, 1976:115-20.

6 Zeman W, Kaebling R, Pasamanick B. Idiopathic dystonia musculorum deformans I. The hereditary pattern. Am f Hum Genet 1959;11:188-202.

7 Marsden CD, Harrison MJG, Bundey S. The natural history of idiopathic torsion dystonia. In: Eldridge R, Fahn S, eds. Dystonia. Advances in neurology. Vol 14. New York: Raven Press, 1976:177-87.

8 Fahn S, Marsden CD, Calne DB. Classification and investigation of dystonia. In: Marsden CD, Fahn S, eds. Movement disorders 2. London: Butterworths, 1987:332-58.

9 Marsden CD. Investigation of dystonia. In: Fahn S, Marsden CD, Calne DB, eds. Dystonia 2. Advances in neurology. Vol 50. New York: Raven Press, 1988:35-44.

10 Nakashima K, Rothwell JC, Day BL, Thompson PD, Shannon $K$, Marsden CD. Reciprocal inhibition between forearm muscles in patients with writer's cramp and other occupational cramps, symptomatic hemidystonia and hemiparesis due to stroke. Brain 1989;112:681-97.

11 Nygaard TG, Marsden CD, Duvoisin RC. Dopa responsive dystonia. In: Fahn S, Marsden CD, Calne DB, eds. Dystonia 2. Advances in neurology. Vol 50. New York: Raven Press, 1988:377-85.

12 Hornykiewicz O, Kish SJ, Becker LE, Farley I, Shannak K. Brain neurotransmitters in dystonia musculorum deformans. $N$ Engl f Med 1986;315:347-53.

13 Hedreen JC, Zweig RM, DeLong MR, et al. Primary dystonias: a review of the pathology and suggestions for new directions of study. In: Fahn S, Marsden CD, Calne DB, eds. Dystonia 2. Advances in neurology. Vol 50. New York: Raven Press, 1988:123-32

14 Truong DD, Fahn S. An early description of dystonia: translocation of Schwalbe's thesis and information on his life. In: Fahn S, Marsden CD, Calne DB, eds. Dystonia 2. Advances in neurology. Vol 50. New York: Raven Press, 1988:651-64.

15 Zeman W. Dystonia: an overview. In: Eldridge R, Fahn S, eds. Dystonia. Advances in neurology. Vol 14. New York: Raven Press, 1976:91-103.

16 Regensburg J. Zur klinik des hereditaren torsiondystonischen symptomkomplexes. Monatsschr Psychiatr Neurol 1930;75: 323-45.

17 Wechsler IS, Brock S. Dystonia musculorum deformans and especial reference to a myostatic form and the occurrence of decerebrate rigidity phenomena. A study of six cases. Arch Neurol Psychiatry 1922;8:538-52.

18 Mankowsky BN, Czerny LI. Zur Frage uber die Hereditat der Torsiondystonie. Monatsschr Psychiatr Neurol 1929;72:165-79.

19 Oppenheim H. Uber Eine eigenartige krampfkrankheit des kindlichen und jugendlichen Alters (dysbasia lordotica progressiva, dystonia musculorum deformans). Neurol Zentralbl 1911;30:1090-107.

20 Mendel K. Torsiondystonie (dystonia musculorum deformans, torsionsspasmus). Monatsschr Psychiatr Neurol 1919;46:309-61.

21 Herz E. Dystonia II. Clinical classification. Arch Neurol Psychiatry 1944;51:319-55.

22 Zeman W, Kaebling R, Pasamanick B. Idiopathic dystonia musculorum deformans II. The formes frustes. Neurology (Minneap) 1960;10:1068-75.

23 Zeman W, Dyken P. Dystonia musculorum deformans. In: Vinken PJ, Bruyn GW, eds. Handbook of clinical neurology. Vol 6. Amsterdam: North Holland, 1968:517-43.

24 Johnson W, Schwartz G, Barbeau A. Studies in dystonia musculorum deformans. Arch Neurol 1962;7:301-13.

25 Larsson T, Sjogren T. Dystonia musculorum deformans. A genetic and clinical population study of 121 cases. Acta Neurol Scand (Suppl) 1966;17:1-232.

26 Yanagisawa N, Goto A, Narabayashi $H$. Familial dystonia musculorum deformans and tremor. $\mathcal{f}$ Neurol Sci 1972;16: 125-36.

27 Eldridge R. The torsion dystonias: literature review and genetic and clinical studies. Neurologv (Minneap) 1970;20 (suppl): 1-78.
28 Eldridge $R$, Gottlieb $R$. The primary hereditary dystonias: genetic classification of 768 families and revised estimate of gene frequency, autosomal recessive form and selected bibliography. In: Eldridge R, Fahn S, eds. Dystonia. Advances in neurology. Vol 14. New York: Raven Press, 1976:457-74

29 Eldridge R, Koerber T. Torsion dystonia: autosomal recessive form. In: Goodman RM, Motulsky AG, eds. Genetic diseases among Ashkenazi fews. New York: Raven Press, 1979:231-51.

30 Korczyn AD, Zilber N, Kahana E, Alter $M$. Inheritance of torsion dystonia. Ann Neurol 1981;10:204-5.

31 Burke RE, Brin MF, Fahn S, Bressman SB, Moskowitz C. Analysis of the clinical course of non-Jewish, autosomal dominant torsion dystonia. Movement Disorders 1986;1:163-78.

32 Inzelberg $R$, Kahana $E$, Korczyn AD. Clinical course of idiopathic torsion dystonia among Jews in Israel. In: Fahn S, Marsden CD, Calne DB, eds. Dystonia 2. Advances in neurology. Vol 50. New York: Raven Press, 1988:93-100.

33 Oswald A, Silber M, Goldblatt J. Autosomal recessive idiopathic torsion dystonia in a kindred of mixed ancestry. $S$ Afr Med $\mathcal{J}$ 1986;69:18-20.

34 Gimenez-Roldan S, Delgado G, Marin M, Villanueva JA, Mateo D. Hereditary torsion dystonia in Gypsies. In: Fahn S, Marsden CD, Calne DB, eds. Advances in neurology. Vol 50. New York: Raven Press, 1988:73-81.

35 Lee LV, Pascasio FM, Fuentes FD, Viterbo GH. Torsion dystonia in Panay, Philippines. In: Eldridge R, Fahn S, eds. Dystonia. Advances in neurology. Vol 14. New York: Raven Press, 1976:137-51.

36 Fahn S, Moskowitz C. X-linked recessive dystonia and Parkinsonism in Filipino males. Ann Neurol 1988;24:179.

37 Fletcher NA, Harding AE, Marsden CD. A genetic study of idiopathic torsion dystonia in the United Kingdom. Brain 1990;113:379-95.

38 Zilber N, Korczyn AD, Kahana E, Fried K, Alter M. Inheritance of idiopathic torsion dystonia among Jews. F Med Genet 1984;21:13-20.

39 Bressman SB, de Leon D, Brin MF, et al. Idiopathic dystonia among Ashkenazi Jews: evidence for autosomal dominant inheritance. Ann Neurol 1989;26:612-20.

40 Korczyn AD, Kahana E, Zilber N, Streifler M, Carasso K, Alter $M$. Torsion dystonia in Israel. Ann Neurol 1980;8:387-91.

41 Burke RE, Fahn S, Marsden CD, Moskowitz C, Friedman J. Validity and reliability of a rating scale for the primary torsion dystonias. Neurology (Minneap) 1985;35:73-7.

42 Couch JR. Dystonia and tremor in spasmodic torticollis. In: Eldridge R, Fahn S, eds. Dystonia. Advances in neurology. Vol 14. New York: Raven Press, 1976:245-58.

43 Critchley M. Observations on essential tremor. Brain 1949;72: $113-39$

44 Baxter DW, Lal S. Essential tremor and dystonic syndromes. In: Poirier LJ, Sourkes TL, Bedard PJ, eds. The extrapyramidal system and its disorders. Advances in neurology. Vol 24. New York: Raven Press, 1979:373-7.

45 Rosenbaum F, Jankovic J. Focal task specific tremor and dystonia: categorisation of occupational movement disorders. Neurology (Minneap) 1988;38:522-7.

46 Jankovic J, Van der Linden C. Dystonia and tremor induced by peripheral trauma: predisposing factors. $\mathcal{f}$ Neurol Neurosurg Psychiatry 1988;51:1512-9.

47 Cavalli-Sforza LL, Carmelli D. The Ashkenazi gene pool: interpretations. In: Goodman RM, Motulsky AG, eds. Genetic diseases among Ashkenazi fews. New York: Raven Press, 1979:93-102.

48 Poewe WH, Lees AJ, Stern GM. Dystonia in Parkinson's disease: clinical and pharmacological features. Ann Neurol 1988;23: 73-8.

49 Fletcher NA, Stell R, Harding AE, Marsden CD. Degenerative cerebellar ataxia and focal dystonia. Movement Disorders 1988;3: $336-42$.

50 Ozelius L, Kramer PL, Moskowitz CB, et al. Human gene for torsion dystonia located on chromosome 9q32-q34. Neuron $1989 ; 2: 1427-34$

51 Craig SP, Buckle VJ, Lamouroux A, Mallet J, Craig IW. Localisation of the human dopamine beta hydroxylase (DBH) gene to chromosome 9q34. Cytogenet Cell Genet 1988;48:48-50.

52 Ziegler MG, Lake CR, Eldridge R, Kopin IJ. Plasma norepinephrine and dopamine beta hydroxylase in dystonia. In: Eldridge R, Fahn S, eds. Dystonia. Advances in neurology. Vol 14. New York: Raven Press, 1976:307-18. 